\title{
MANUHARA PERSPEKTIP STRUKTUR, GARAP, DAN FUNGSI
}

\author{
Teguh \\ Jurusan Karawitan, Fakultas Seni Pertunjukan \\ Institut Seni Indonesia Yogyakarta
}

\begin{abstract}
Abstrak
Gending Manuhara Laras Pelog Patet Lima merupakan salah satu gending yang tergolong gending baru, karena gending ini selesai dicipta tanggal 19 September 2013. Adapun pencipta gending Manuhara adalah K.R.R.A. Saptodiningrat. Gending Manuhara berbentuk gending ageng yaitu gending kethuk 2 awis minggah 8, terdiri dari buka, merong, umpak inggah dan inggah. Keistimewaan gending Manuhara adalah pada bagian merong terdiri atas lima kenongan, dan satu-satunya gending laras pelog patet lima yang digarap menggunakan kendang ciblon dan menggunakan sekaran menthokan. Sampai saat sekarang ini tidak ada gending ageng pelog lima yang bisa digarap ciblon. Gending Manuhara dicipta khusus sebagai gending klenengan dan gending ini tercipta dari lagu suluk pelog lma ageng.
\end{abstract}

Kata kunci : Gending Manuhara, Struktur, Garap, Fungsi.

\begin{abstract}
Manuhara Gending Laras Pelog Patet Lima is one of the gending that is classified as a new gending, because it was created on September 19, 2013. The creator of Gending Manuhara was K.R.R.A. Saptodiningrat. Gending Manuhara is in the form of gending ageng, which is ginghuk 2 awis minggah minggah 8, consisting of open, merong, umpak Ingah and Ingah. The special feature of Manuhara gending is that the merong section consists of limakenongan, and the only five pelog patet barrels which are worked using a ciblon drum and now has a menthokan. Until now there has been no gog ageng pelog lima that can be worked on ciblon. Manuhara Gending was created specifically as a musical accompaniment and this song was created from the song pelog lma ageng.
\end{abstract}

Keywords: Gending Manuhara, Structure, Garap, Function. 


\section{A. Pendahuluan}

Gending Manuhara Laras Pelog Patet Lima adalah salah satu gending klasik yang terdapat pada karawitan gaya Surakarta, berbentuk kethuk 2 awis minggah 8. Mengapa Gending Manuhara menarik untuk diteliti, alasannya adalah bahwa; (1) Bisa digarap menggunakan pola kendang batangan atau ciblon; (2) Bagianmerong dengan inggahnya jumlah tabuhan kenong tidak sama, merong terdiri dari 5 kenongan, sedang inggahnya hanya terdiri dari 4 kenongan dalam satu cengkok atau gongan; (3) Bagian inggahnya jenis balungan nibani, hal ini juga berbeda dengan gending yang telah ada sebelumnya, khususnya gending yang berlaras pelog patet lima. Berdasarkan alasan seperti tersebut, dapat dipahami bahwa Manuhara adalah salah satu gending tradisi klasik yang mempunyai keistimewaan bila dibanding dengan gending-gending pelog lima pada umumnya. Keistimewaan yang lain adalah Manuhara tergolong gending ageng, karena gending-gending baru umumnya hanya berbentuk Ladrang dan Ketawang. Menurut Supanggah, Manuhara termasuk gending standar, artinya Manuhara terdiri dari buko, merong, umpak inggah dan inggah bahkan ada gending lain yang penyajiannya selalu berurutan dengan Manuhara (Bothekan Karawitan II, 2009:
Data awal menunjukkan bahwa, sumber gending karawitan gaya Surakarta sampai saat sekarang ini berasal dari Keraton Kasunanan Surakarta, Pura Mangkunegaran, Kepatihan dan Prabuwinatan (Wawancara dengan K.R.T. Radyo Adi Nagoro pada tanggal 2 Desember 2017). Rustopo dalam bukunya yang berjudul "Perkembangan GendingGending Gaya Surakarta 1950-2000 an" menyebutkan gending yang berasal dari 4 sumber itu jumlahnya ada 690 gending (2009: 26). Jumlah itu belum ditambah gending-gending ciptaan personal seperti gending ciptaan RL Martopangrawit, $\mathrm{Ki}$ Ciptosuwarso, Ki Nartosabdho dan yang lainnya yang jumlahnya mungkin ribuan gending.

Gending Manuhara ini berasal dari Kasunanan, Kepatihan, Mangkunegaran atau gending dari Prabuwinatan belum bisa diketahui secara pasti, karena dari ke 4 sumber seperti disebut di atas tidak ada yang menyebut gending Manuhara. Demikian juga buku "Wedhapradangga" yang merupakan sumber sejarah gending karawitan gaya Surakarta sama sekali tidak menyebut Gending Manuhara.

Fakta seperti tersebut di atas dapat dipahami bahwa Gending Manuhara adalah gending tradisi klasik tergolong gending yang relatif baru. Walaupun mungkin tergolong gending "baru" tetapi 
jika dilihat susunan melodi lagu merong dengan inggahnya sama, susunan melodi seperti ini mempunyai kesamaan dengan gending klasik yang sudah ada sebelumnya. Dan susunan melodi merong dengan inggahnya sama dalam dunia karawitan Surakarta lazim disebut gending inggah kendang. Namun demikian untuk menjawab keraguan ini perlu penelitian lebih lanjut.
Dalam "Kamus Jawa Kuna Indonesia" tulisan L. Mardiwarsito disebutkan istilah gending dapat dipahami sebagai komposisi lagu gamelan (1990: 190).Martopangrawit, dalam bukunya yang berjudul "Pengetahuan Karawitan" menjelaskan difinisi gending sebagai berikut:

\section{Pengertian Gending Manuhara}

Berbicara tentang karawitan tentu tidak akan lepas dari istilah gending.

Didalam perihal lagupun akan kami batasi pembicaraan kami yaitu masalah lagu hubungannya dengan gending. Adapun arti lagu adalah: susunan nada-nada yang diatur dan apabila dibunyikan sudah terdengar enak. Pengaturan nada-nada tersebut nantinya berkembang kea rah suatu bentuk, sehingga menimbulkan bermacam-macam bentuk dan bentuk-bentuk inilah yang selanjutnya disebut gending (1975: 4).

Dibagian lain juga disebutkan bahwa gending hanya digunakan untuk menunjukkan komposisi musikal karawitan dengan bentuk kethuk 2 kerep dan gending lainnya dengan bentuk yang lebih besar (Martopangrawit, 1975: 5).

\begin{abstract}
Selanjutnya gending pada karawitan gaya Surakarta dapat diklasifikasikan berdasar ukuran atau jumlah susunan kerangka lagu (gatra) pada
\end{abstract} setiap komposisinya. Gending pada dasarnya dapat dikelompokkan menjadi tiga yakni gendingalit, gendingtengahan, dangending ageng.Gending-gending alit adalah gending dengan bentuk ladrang, ketawang, ayak-ayakan. Gending-gending dengan bentuk kethuk 2 kerep dan Ketawang gending kethuk 2kerepmasuk dalam kelompok gending

\section{tengahan.SedangkanGending-gending} yang dikelompokkan ke dalam gending ageng adalah gending dengan bentuk kethuk 4 kerep, kethuk 4 awis dan kethuk 8 kerep (khusus untuk laras pelog).Dalam hal ini Supanggah menjelaskan bahwa bentuk gending sebenarnya tidak hanya ditentukan dari susunan kalimat lagu, melainkan dapat ditentukan dengan pengaturan letak tabuhan ricikan struktural (BothekanKarawitan II: Garap; 2009: 119). Berdasarkan pengelompokan gending seperti tersebut, maka dapat 
diketahui bahwa Manuhara termasuk minta disayangi.Pada saat penulis gending ageng karena Manuhara diformat berbincang-bincang mengenai Gending sebagai gending kethuk 2 awis.Istilah manuhara sendiri mempunyai arti; indah, Manuhara dengan K.R.T. Radyo Adi Nagoro, mengatakan sebagai berikut: menggiurkan, menghibur, merayu dan

Gending Manuhara pélog lima kui sanadyan kalêbu gending anyar nanging rasa gending, bobot lan laguné balungan runtut bangêt. Malah Manuhara kui nduweni keistiméwaan mêrga mérongé ana lima kênongan, nanging inggahé mung patang kênongan, lan uga duwé rasa prênès jalaran nganggo kêndhangan ménthogan (Wawancara pada tanggal 20 April 2018 di kediamannya Dukuh Sraten, Klaten).

Terjemahan : Gending Manuhara pelog lima itu walaupun termasuk gending baru, tetapi rasa gending, bobot dan lagu balungannya sangat runtut. Kecuali itu Manuhara mempunyai keistimewaan karena pada bagian merong terdiri dari limakenongan, dan inggahnya terdiri dari empat kenongan. Di samping itu mempunyai rasa prenes karena dikendangi dengan pola kendhangan menthogan. Perlu diketahui bersama, bahwa tidak semua gending karawitan gaya Surakarta dapat dikendhangi dengan kendhangan menthogan. Senada dengan penjelasan K.R.T. Radyo Adi Nagoro, K.R.A.T. Broto Adi Nagoro mengatakan seperti berikut :

Gending Manuhara rasané kaya gending-gending sing wis ana sak durungé, ana prênés lan uga ana rasa agung. Malah sak suwéné aku dadi pêngrawit mliginé pêngrêbab aku durung naté nemoké gending pelog lima sing bentuké gêdé iso digarap nganggo kêndhangan ciblon. Miturut aku manuhara kui kalêbu gending apik, mêrga balungané gampang diapalakélan yo ugo gampang garapé(Wawancara pada tanggal 2 Juli 2018 di Keraton Surakarta).

Terjemahan: Gending Manuhara mempunyai rasa seperti gending-gending yang lain yang telah ada sebelumnya, ada rasa prenes dan rasa agung. Selama saya menjadi pengrawit terutama penabuh rebab selama ini, belum pernah menemukan gending ageng pelog lima yang bisa digarap dengan pola kendhang ciblon. Menurut saya gending Manuhara itu termasuk gending yang bagus karena balungannya mudah dihapal dan juga mudah digarap. Memang sebelum tersusun Gending Manuhara dalam dunia karawitan gaya Surakarta belum pernah ada gending laras pelog patet lima sebesar gending ini yang digarap dengan teknik kendangan ciblon. Adapun yang telah ada dan selalu digarap ciblon hanyalah Gending 
Logondang kethuk 2 kerep minggah

\section{B. Metode Penelitian}

Pendekatan penelitian yang digunakan dalam penelitian ini adalah pendekatan kualitatif. Pendekatan kualitatif oleh Cresswell didefinisikan sebagai fakta yang menerangkan bahwa penelitian kualitatif difokuskan pada proses yang terjadi dalam penelitian. Hal ini menunjukkan bahwa penelitian kuantitatif tidak dapat dibatasi. Disamping itu, peneliti merupakan bagian yang penting dalam penelitian untuk memahami gejala sosial terjadi dalam proses penelitian. Penulis memilih jenis penelitian deskriptif karena penulis ingin menggambarkan secara detail dan menginterpretasikan data atau gejala yang diperoleh selama penelitian berlangsung. Jenis penelitian ini juga dipilih karena sesuai dengan tujuan penelitian, yang
Ladrang Eling-eling laras pelog patet lima. menurut penulis lebih tepat dilakukan dengan jenis penelitian diskriptif, sehingga penulis akan untuk menggambarkan secara detail kontruksi gendhing manuhara dalam berbagai perspektif. Penelitian deskriptif dimaksudkan untuk eksplorasi dan klarifikasi mengenai sesuatu fenomena atau kenyataan sosial, dengan jalan mendeskripsikan sejumlah variabel yang berkenaan dengan masalah dan unit yang diteliti. Fenomena dari penelitian ini adalah karakteristik gendhing manuhara yang disebut gending ageng. Fenomena tersebut kemudian di eksporasi sebanyak mungkin yang salah satunya berkaitan dengan wilayah intramusikalekstramusikalnya. Fenomena tersebut diklarifikasi kepada beberapa narasumber untuk memperoleh data yang valid, sehingga konsep intra-ekstramusikalnya dapat dijelaskan dalam konteks keilmuan

\section{Hasil dan Pembahasan}

\section{Struktur Gending Manuhara}

Struktur Gending Manuhara diketahui terdiri daribuka, merong, umpak inggah dan inggah. Di bawah ini adalah balungan Gending Manuhara Laras Pelog Patet Lima:

Buka:

$$
\begin{array}{llllllll}
\ldots 3 & 2165 & .5 .3 & 2165 & 5612 & .1 .6 & 2321 & 6545
\end{array}
$$

\section{Merong:}




$$
\begin{aligned}
& \begin{array}{lllllllll} 
& .56 & 1232 & \ldots 21 & 6123 & 0253 & 2121 & 5612 & .165
\end{array} \\
& \begin{array}{lllllllll} 
& .56 & 1232 & \ldots 21 & 6123 & .253 & 2121 & 5612 & .165
\end{array} \\
& 33 \ldots 3323 \quad 253 \quad 2121 \quad \ldots 12 \quad 4565 \quad 6542 \quad 1216 \\
& \begin{array}{lllllll}
.61 & 2.32 & .321 & 6545 & .5 & 6545 & .45 .6542
\end{array} \\
& \begin{array}{lllllllll} 
& .24 & 5.65 & 456 & 5421 & \ldots 12 & 3216 & 2321 & 6545
\end{array}
\end{aligned}
$$

Umpak inggah

$$
\begin{aligned}
& .1 .6 .1 .5 .1 .6 .1 .2 .3 .1 .3 .2 .3 .1 .6 .5 \\
& \text { Inggah } \\
& .2 .1 .6 .5 .2 .1 .2 .3 \quad 5.3 .5 .3 \quad 6.5 .2 .1 \\
& .2 .1 \quad .6 .5 \quad .2 .1 \quad .2 .3 .5 .3 \quad .5 .3 \quad .6 .5 \quad .2 .1
\end{aligned}
$$

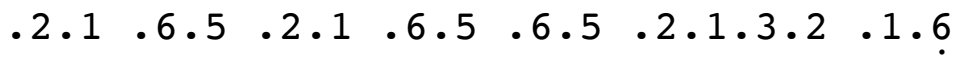

$$
\begin{aligned}
& .1 .6 .1 .5 \quad 1.6 .1 .2 \quad .3 .1 .3 .2 \quad .3 .1 .6 .5
\end{aligned}
$$

\section{Gending Manuhara Berdasarkan Struktur Ricikan Struktural}

Selain ditentukan dari susunan nadanya, bentuk gending juga ditentukan oleh struktur/pola tabuhan ricikan struktural.Gending Manuhara memiliki struktur tabuhan ricikanstruktural yang terdiri dari kempyang, kethuk, kenong dan gong.Khusus untuk ricikan kempyang ditabuh pada bagian inggah saja. Pola tabuhan kethuk berfungsi untuk menandai cara pengkalimatan lagu, pada bagian merong pola tabuhan kethuk terletak pada gatra kedua dan gatra keenam. Jadi, setiap dua tabuhan kethuk tersebut menandai satu kalimat lagu. Sedangkan setiap kalimat lagu akan ditandai oleh tabuhan kenong. Dengan demikian, letak tabuhan kenong 
dapat dianalogikan sebagai titik yang menandai selesainya sebuah kalimat lagu dengan bentuk dan kesan yang utuh.Selanjutnya titik akhir dari susunan kalimat lagu gending ditandai dengan tabuhan gong tersebut sekaligus menandai ukuran bentuk gending. Dibawah ini adalah pola tabuhan ricikan struktural:

Buka:

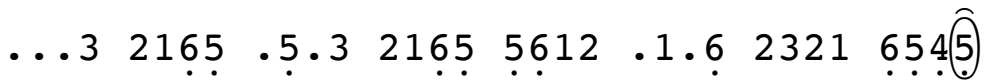

Merong:

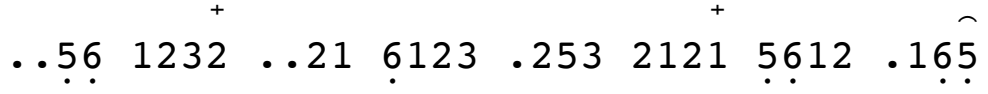

$$
\begin{aligned}
& \begin{array}{lllllllll} 
& .56 & 1232 & \ldots 21 & 6123 & .253 & 2121 & 5612 & .165
\end{array}
\end{aligned}
$$

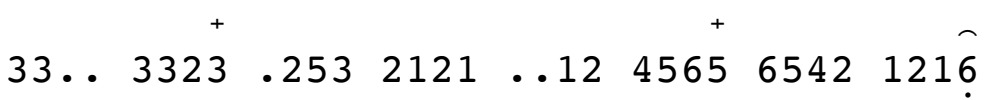

$$
\begin{aligned}
& \begin{array}{lllllllll}
0.61 & 2.32 & .321 & 6545 & .5 & 6545 & .45 & 6542
\end{array}
\end{aligned}
$$

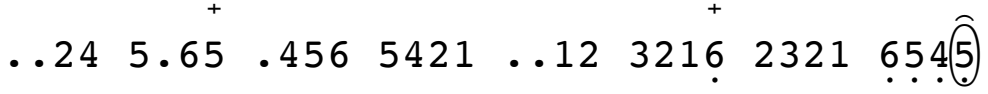

Umpak inggah

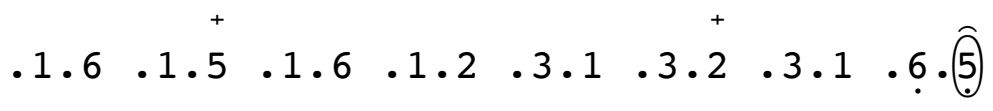

Inggah

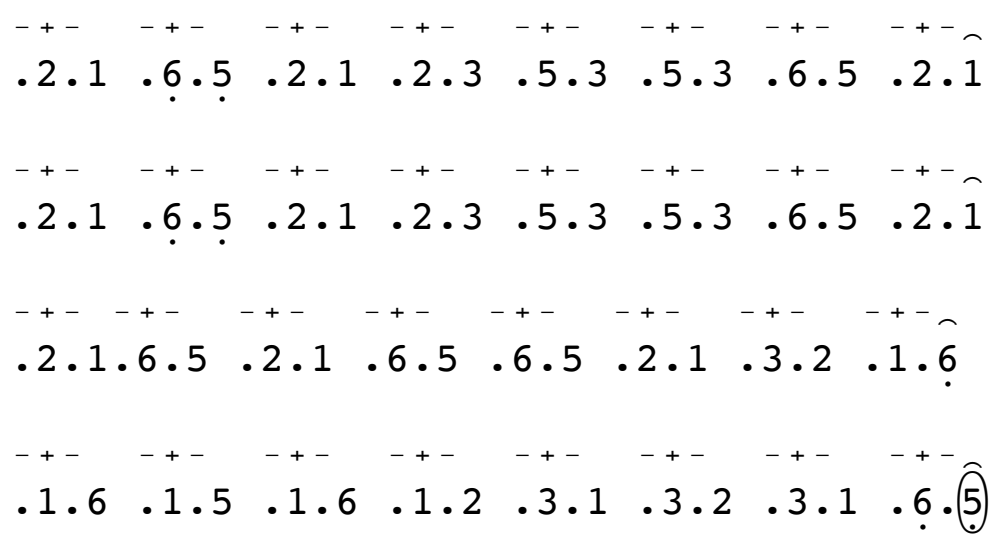

Dengan demikian pola tabuhan ricikan struktural dan kerangka balungan dalam satu gonganadalah sebagai berikut: a. Pada bagian merong terdiri dari:
- 2 tabuhan kethuk: masingmasing tabuhan kethuk terletak pada seleh gatra kedua dan keenam setiap tabuhan kenong. 
- 5 tabuhan kenong: letak tabuhan kenong sebagai penanda kalimat lagu terletak pada seleh gatra terakhir pada gatra ke $8,16,24,32$ dan 40 .

- 1 tabuhan gong: letak tabuhan gong terletak pada seleh gatra ke 40 atau pada kerangka balungan ke 160.

b. Pada bagian umpak inggah terdiri dari:

- 2 tabuhankethuk: masing-masing tabuhan kethuk terletak pada seleh gatra kedua dan keenam setiap tabuhan kenong.

- 1 tabuhan gong: letak tabuhan gong terletak pada seleh gatra ke 40 atau pada kerangka balungan ke 160.

c. Pada bagian inggah terdiri dari:

- 16 tabuhankempyang: masingmasing tabuhan kempyangterletak pada slah balungan atau hitungan pertama dan ketiga setiap gatra pada setiaptabuhan kenong.

- 8 tabuhan kethuk: masingmasing tabuhan kethuk terletak pada hitungan kedua pada setiap gatra dan pada setiap tabuhan kenong.

- 4 tabuhan kenong: masingmasing tabuhan kenong terletak pada gatra ke 8, 16, 24 dan 32 .
- 1 tabuhan gong: letak tabuhan gong terletak pada seleh gatra ke 32 atau pada kerangka balungan ke 128.

\section{Proses Terjadinya Gending Manuhara}

K.R.R.A.Saptodiningrat

mengatakan bahwa gending Manuhara, tercipta atau tersusun terinspirasi dari sebuah lagu yang disebut Pathetan PelogLima.Pathetan pelog lima adalah sebuah orkestrasi yang terdiri dari lagu; vocal bersama (suluk grubyuk), rebaban, genderan, gambangan dan sulingan dengan pola sistem pelog lima. Pathetan ini selalu disajikan setiap hari Selasa Kliwon atau anggara kasih (35 hari sekali) mengawali penyajian tari BedhayaKetawang yang merupakan salah satu pusaka keraton Surakarta.Lebih lanjut dikatakan oleh Saptodiningrat bahwa Gending Manuhara,kethuk 2 awis minggah 8 laras pelog patet lima ini selesai disusun pada tanggal 19 September 2013. Dan gending Manuhara telah dipersembahkan kepada Susuhunan Paku Buwono XIII, Keraton Kasunanan Surakarta, sejak itu pula maka Gending Manuhara merupakan gending Keraton, melengkapi gending yang telah ada sebelumnya (Wawancara pada tanggal 2 Mei 2018 di Makamhaji, Surakarta).

Gending Manuhara ini dicipta atau disusun diharapkan juga untuk mengikuti 
perubahan budaya meliputi kehidupan berkesenian khususnya seni karawitan, yang mana setiap penyajian karawitan pada malam hari sejak sore telah disajikan gending-gending prenes yang terasa gembira, oleh karena itu Gending Manuhara pantas pula bila ikut disajikan, sebab dalam tradisi selama ini penyajian karawitan atau lazim disebut klenéngan dimalam hari gending-gending ber-laras pelog lima selalu disajikan pada bagian awal (Wawancara pada tanggal 3 Mei 2018 di Makamhaji, Kartosura, Surakarta).

$$
\text { Penjelasan K.R.R.A. }
$$

Saptodiningrat seperti tersebut di atas dapat dipahami bahwa Manuhara merupakan bentuk gending ageng dan tergolong masih muda. Lahirnya gending ageng seperti Manuhara ini setidaktidaknya dalam dunia karawitan Surakarta bertambah vokabuler gending, dan menjadi alternatip lain bilamana para pengrawit akan menyajikan gending pelog lima. Menurut penjelasan K.R.R.A. Saptodiningrat, Gending Manuhara dibuat atau dicipta bukan sebagai gending iringan atau untuk keperluan mengiringi seni tari, pakeliran dan atau seni lainnya melainkan Manuhara dibuat khusus untuk disajikan pada format klenéngan.Namun demikian tidak menutup kemungkinan bahwa Manuhara juga bisa dipakai sebagai gending iringan (Wawancara pada tanggal 5 Juni 2018 di Makamhaji, Surakarta).

\section{Garap Gending Manuhara}

Merujuk penjelasan Supanggah dalam buku "Bothekan Karawitan II: Garap”, istilah garap dalam karawitan adalah merupakan rangkaian kerja kreatif dari (seorang atau kelompok) pengrawit dalam menyajikan sebuah gending atau komposisi karawitan untuk dapat menghasilkan wujud (bunyi), dengan kualitas atau hasil tertentu sesuai dengan maksud, keperluan atau tujuan dari suatu kekaryaan atau penyajian tradisi (2009: 4). Penjelasan Supanggah ini dapat dipahami bahwa pengrawit ketika menyajikan gending haruslah mempunyai kreatifitas dalam menggarap gending. Karena gending itu pada dasarnya hanya berujud balungan atau notasi saja. Untuk dapat menjadi sebuah sajian yang enak notasi balungan itu haruslah ditafsir garapnya, terutama oleh ricikan garap, seperti rebab, kendang, gender barung dan bonang barung.

Di bawah ini akan dituliskan garap ricikan rebab Gending Manuhara yang direkam khusus untuk penelitian ini. Adapun grup karawitan yang direkam adalah grup karawitan Sapto Budoyo Surakarta. 


\section{Ricikan Rebab}

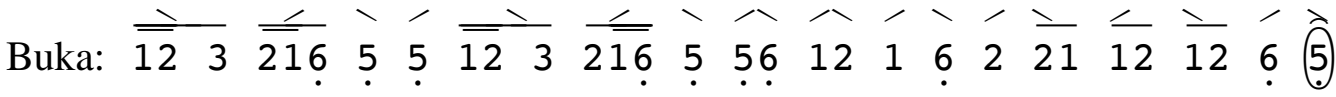

Merong:

$$
\begin{aligned}
& \begin{array}{rlllllllllllll}
\text { - } & 5 & 6 & 1 & 2 & 3 & 2 & \text {. } & \text {. } & 2 & 16 & 1 & 2 & 3
\end{array} \\
& \begin{array}{llllllllllllll}
5 & 5 & 5 & 6 & 1 & \overline{2} 3 \overline{232} 2 & 2 & 2 & \overline{23} & \overline{12} & \overline{62} & \overline{12} & \overline{23} & 3
\end{array}
\end{aligned}
$$

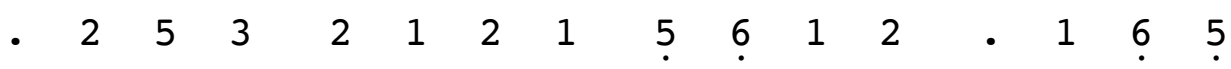

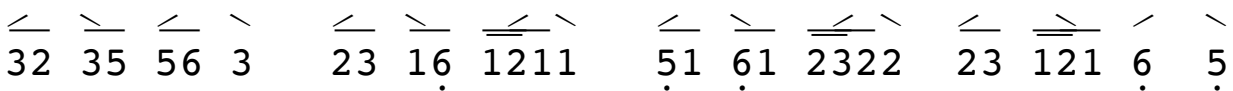

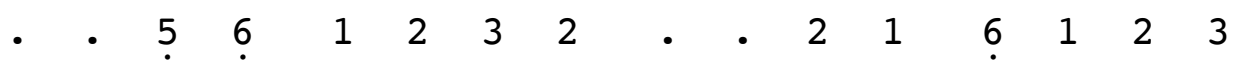

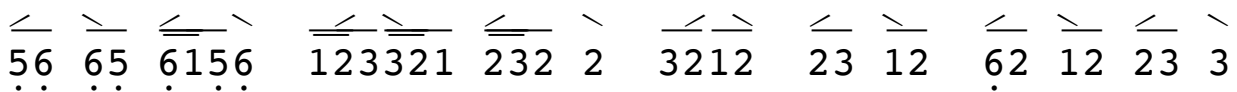

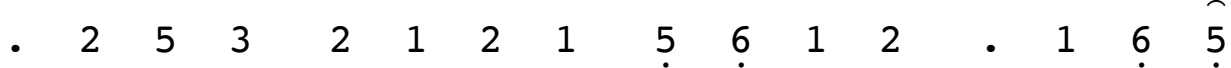

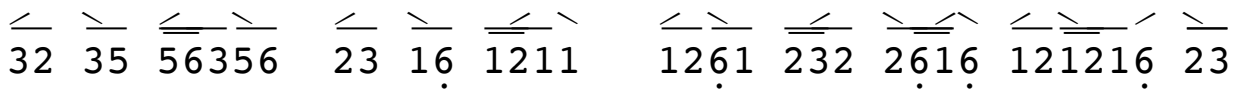

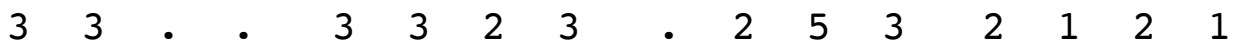

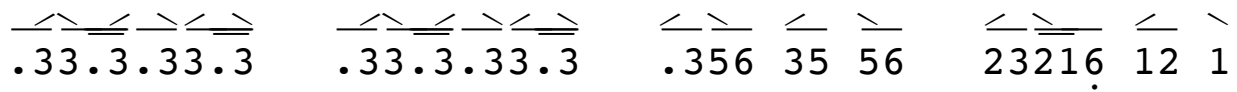$$
\begin{array}{rllllllllllllll}
\text { - } & 1 & 2 & 4 & 5 & 6 & 5 & 6 & 5 & 4 & 2 & 1 & 2 & 1 & \hat{6}
\end{array}
$$

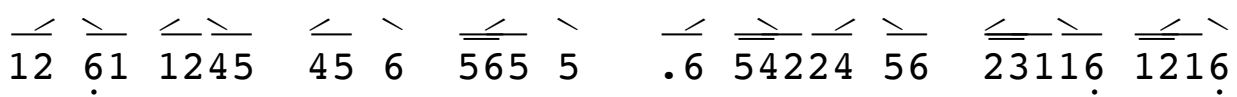

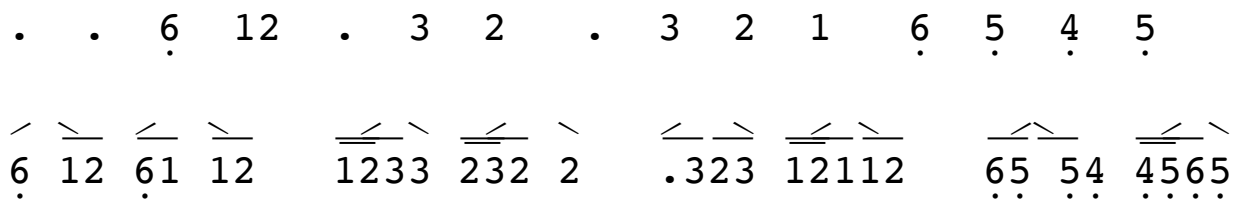

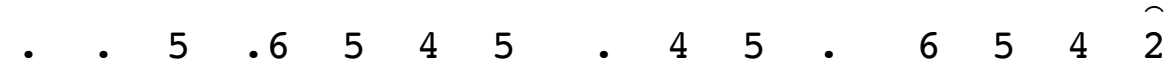




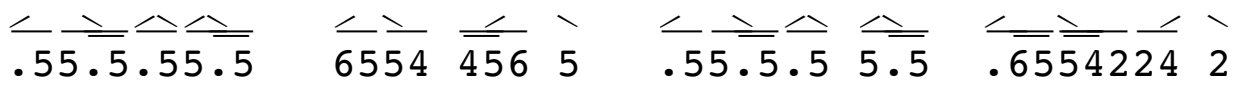

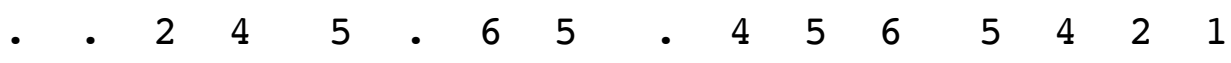

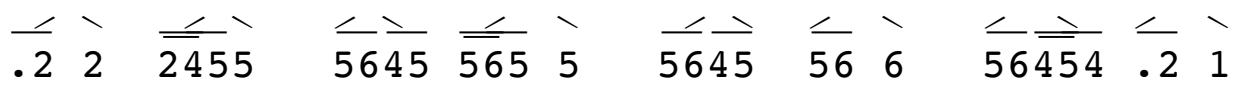

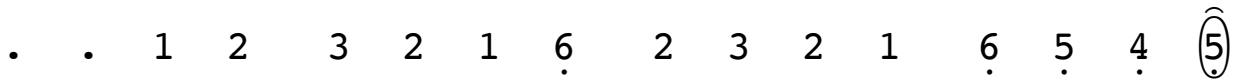

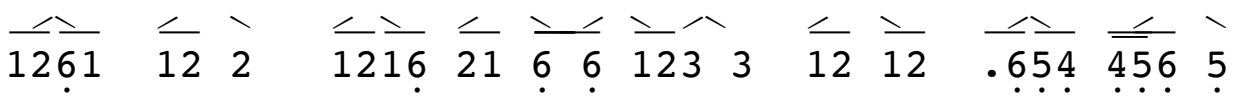

Umpak Inggah:

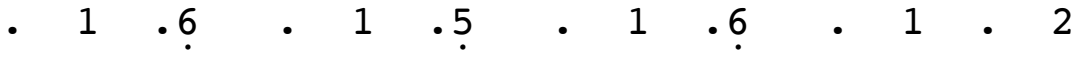

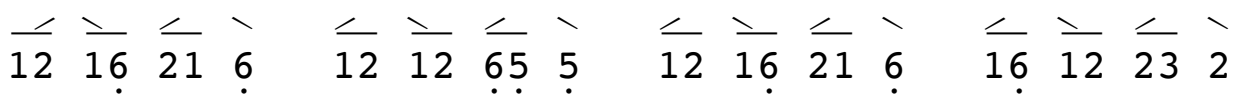

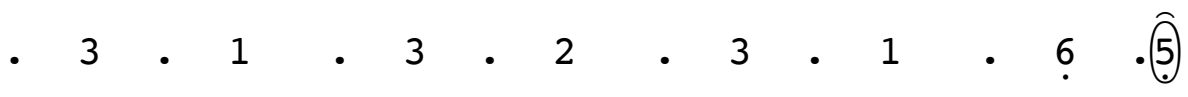

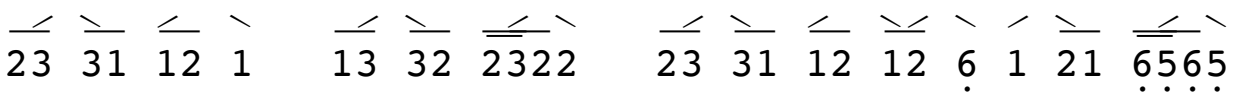

Inggah:

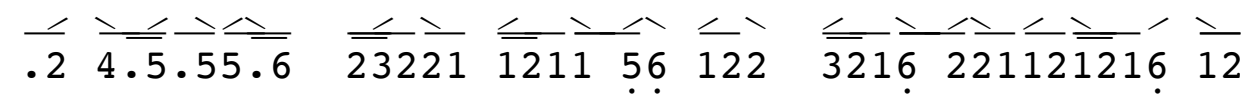

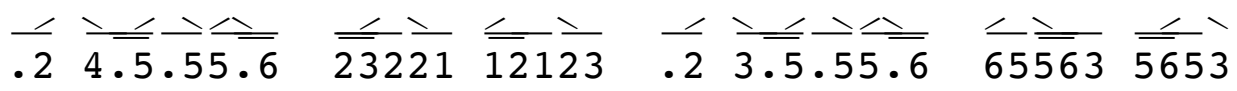

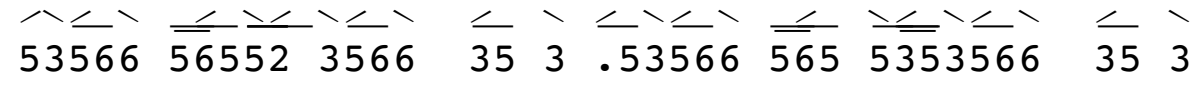




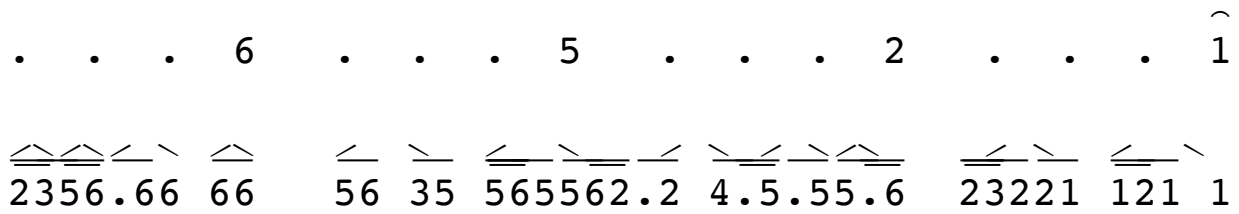

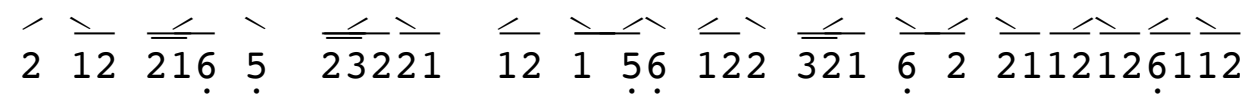

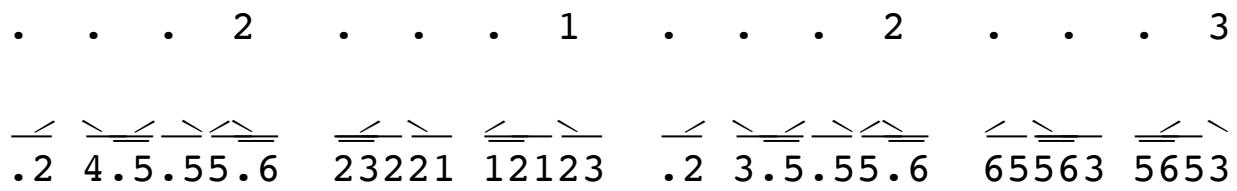

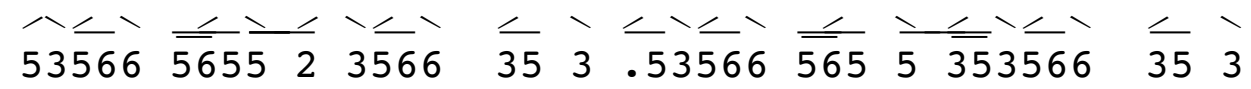

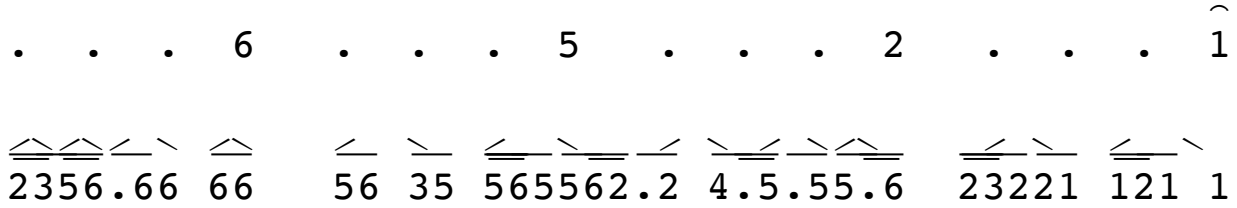

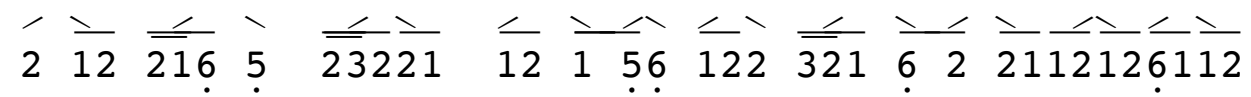

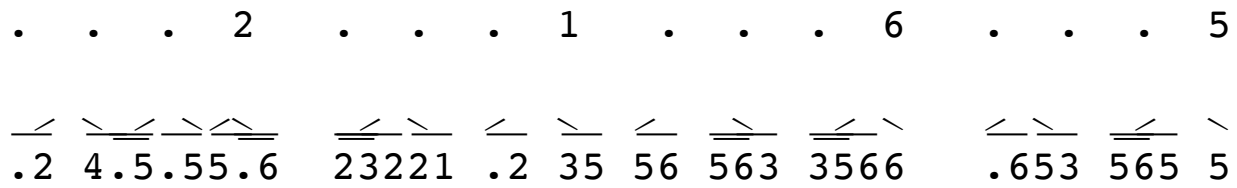

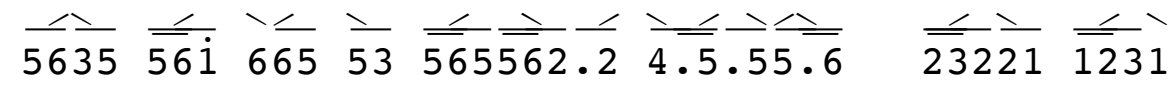




\section{Ricikan Kendang}

Kendang yang digunakan untuk Gending Manuhara adalah kendang ageng, kendang ketipung dan kendang ciblon atau batangan. Sedangkan penggunaan kendang itu ialah kendang ageng dan kendang ketipung digunakan pada bagian merong, sedangkan pada bagian inggah menggunakan kendang ciblon. Berikut adalah hasil transkrip dari rekaman pada bagian merong.

Tabel 1. Hasil transkrip dari rekaman merong

\begin{tabular}{|l|l|l|l|l|l|l|l|l|}
\hline Nama & 1 & 2 & 3 & 4 & 5 & 6 & 7 & 8 \\
\hline BL & $\ldots 5$ & 123 & $\ldots 2$ & 612 & .25 & 212 & 5.612 & .165 \\
& 6 & 2 & 1 & 3 & 3 & 1 & & \\
\hline KD & $\circ \rho \circ$ & $\circ \rho \circ$ & $\circ \circ \rho$ & $\circ \circ \circ$ & $\circ \circ \rho$ & $\circ \rho \circ$ & $\circ f \circ \rho$ & $\circ \circ 6 \circ$ \\
& $\circ$ & 6 & $\circ$ & $\rho$ & $\circ$ & $t$ & & \\
\hline
\end{tabular}


Jurnal Etnomusikologi

\begin{tabular}{|c|c|c|c|c|c|c|c|c|}
\hline $\mathrm{BL}$ & $\begin{array}{l}\cdots 5 \\
6\end{array}$ & $\begin{array}{l}123 \\
2\end{array}$ & $\begin{array}{l}\ldots 2 \\
1\end{array}$ & $\begin{array}{l}612 \\
3\end{array}$ & $\begin{array}{l}.25 \\
3\end{array}$ & $\begin{array}{l}212 \\
1\end{array}$ & 5612 & $.16 \hat{5}$ \\
\hline KD & $\begin{array}{l}\circ p \circ \\
\circ\end{array}$ & $\begin{array}{l}\circ p \circ \\
b\end{array}$ & $\begin{array}{l}\circ \circ p \\
\circ\end{array}$ & $\begin{array}{l}\circ \circ \circ \\
p\end{array}$ & $\begin{array}{l}\circ \circ p \\
\circ\end{array}$ & $\begin{array}{l}\circ p \circ \\
t\end{array}$ & $\circ f \circ p$ & $\circ \circ b^{\circ}$ \\
\hline $\mathrm{BL}$ & $\begin{array}{l}33 . \\
.\end{array}$ & $\begin{array}{l}332 \\
3\end{array}$ & $\begin{array}{l}.25 \\
3\end{array}$ & $\begin{array}{l}212 \\
1\end{array}$ & $\begin{array}{l}\ldots 1 \\
2\end{array}$ & $\begin{array}{l}456 \\
5\end{array}$ & 6542 & $121 \hat{6}$ \\
\hline KD & $\begin{array}{l}\circ p \circ \\
\circ\end{array}$ & $\begin{array}{l}\circ p \circ \\
b\end{array}$ & $\begin{array}{l}\circ \circ p \\
\circ\end{array}$ & $\begin{array}{l}\circ \circ \circ \\
p\end{array}$ & $\begin{array}{l}\circ \circ p \\
\circ\end{array}$ & $\begin{array}{l}\circ p \circ \\
t\end{array}$ & $\circ f \circ p$ & oof \\
\hline $\mathrm{BL}$ & $\begin{array}{l}\cdots 6 \\
1\end{array}$ & $\begin{array}{l}2.3 \\
2\end{array}$ & $\begin{array}{l}.32 \\
1\end{array}$ & $\begin{array}{l}654 \\
5\end{array}$ & $\begin{array}{l}. .5 \\
.\end{array}$ & $\begin{array}{l}654 \\
5\end{array}$ & .45 & $654 \hat{2}$ \\
\hline KD & $\begin{array}{l}\circ p \circ \\
\circ\end{array}$ & $\begin{array}{l}\circ p \circ \\
b\end{array}$ & $\begin{array}{l}\circ \circ p \\
\circ\end{array}$ & $\begin{array}{l}\circ \circ \circ \\
p\end{array}$ & $\begin{array}{l}\circ \circ p \\
\circ\end{array}$ & $\begin{array}{l}\circ p \circ \\
t\end{array}$ & $\circ f \circ p$ & ०of० \\
\hline $\mathrm{BL}$ & $\begin{array}{l}\ldots 2 \\
4\end{array}$ & $\begin{array}{l}5.6 \\
5\end{array}$ & $\begin{array}{l}.45 \\
6\end{array}$ & $\begin{array}{l}542 \\
1\end{array}$ & $\begin{array}{l}\ldots 1 \\
2\end{array}$ & $\begin{array}{l}321 \\
6\end{array}$ & 2321 & $654(5)$ \\
\hline KD & $\begin{array}{l}\circ \circ p \\
\circ\end{array}$ & $\begin{array}{l}\circ \circ \circ \\
p\end{array}$ & $\begin{array}{l}\circ \circ p \\
\circ\end{array}$ & $\begin{array}{l}\circ p \circ \\
b\end{array}$ & $\begin{array}{l}\circ \rho \circ \\
\circ\end{array}$ & $\begin{array}{l}\circ p \circ \\
b\end{array}$ & $\circ p \circ \circ$ & $b p \circ \widehat{0}$ \\
\hline OI & $\begin{array}{l}.1 . \\
6\end{array}$ & $\begin{array}{l}.1 . \\
5\end{array}$ & $\begin{array}{l}.1 . \\
6\end{array}$ & $\begin{array}{l}.1 \text {. } \\
2\end{array}$ & $\begin{array}{l}.3 \\
1\end{array}$ & $\begin{array}{l}.3 \\
2\end{array}$ & .3 .1 & 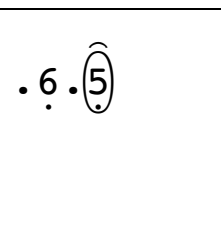 \\
\hline KD & $\circ \circ \circ$ & $\circ \circ \circ$ & $\circ \circ \circ$ & $\circ \circ \circ$ & oto & of 0 & $\circ p \circ \overline{f \circ}$ & $\overline{\circ t} \overline{\circ p} \overline{\circ \circ} \overline{\circ(0)}$ \\
\hline
\end{tabular}




\begin{tabular}{|l|l|l|l|l|l|l|l|l|}
\hline & $P$ & $P$ & $P$ & $b$ & $P$ & $P$ & & \\
\hline
\end{tabular}

\section{Keterangan:}

Gending Manuhara Laras Pelog Patet Lima, dalam penelitian ini baik bagian merong maupun bagian inggah masing-masing disajikan dua gongan atau dua ulihan. Titilaras kendangan seperti tersebut diatas adalah titilaras kendang ageng, titilaras kendang penunthung terletak pada hitungan kedua dan ketiga setiap gatranya. Adapun urutan penyajiaannya adalah sebagai berikut;

\section{Merong}

- Diawali buka ricikan rebab, ditampani atau diterima kendang ageng setelah gong buka pada gatra pertama dan kedua digarap menggunakan irama lancar, mulai gatra ketiga sampai dengan gatra keenam digarap menggunakan irama tanggung, selanjutnya irama dadi disajikan mulai gatra ketujuh kenong pertama sampai dengan gong.
- Peralihan dari merong ke inggah melalui umpak inggah dilakukan setelah kenong ketiga.

- Perubahan irama dari dadi ke irama tanggung dimulai dari gatra ketiga kenong keempat.

- Pada kenong kelima, balungan ganti balungan umpak inggah, menjelang gong umpakinggah satu gatra menjelang gong, irama berubah lagi menjadi dadi.

-Pada inggah, irama dadi disajikan sampai dengan gatra ketiga, selanjutnya mulai gatra keempat irama menjadi wilet menggunakan kendang ciblon.

2. Inggah

Pada bagian inggah, digarap menggunakan polakendangan ciblon.Hasil dari permainan kendang ciblon, rasa gending menjadi gumyak, gayeng, prenes dan bahkan gecul

\section{Pola kendangan Angkatan Ciblon Irama Wiled}

\section{$t \quad \underline{\rho p} \circ \overline{p l} \circ \overline{p l} \circ \overline{\rho l} \overline{t h} b \quad b \overline{k t} \overline{k p} t \rho b$

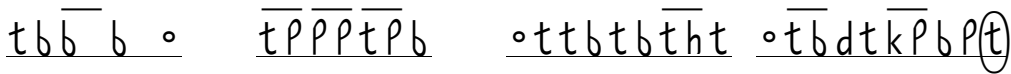

\section{Pola Kendangan Sekaran Pokok}

a. Sekaran Batangan (SB)

Ia: $\quad \quad \quad b \rho t \overline{k b} 0 \overline{k b} t \overline{p p} p \rho \overline{\rho l} \bar{k} p t \rho b$ 
Ib: $\quad d \overline{t h} b b d 0 \overline{. h} \overline{t b} \overline{\rho l} d \overline{\rho l} d \overline{b d} b d I$

b. Sekaran Gong Batangan (GB)

$$
0 \overline{k t k P t \rho} \overline{\rho d} \overline{\rho e} \overline{b d} b \overline{b b} \cdot b \quad b \overline{k \rho} \overline{\rho e} \overline{b d}(b)
$$

c. Sekaran II (Pilesan)

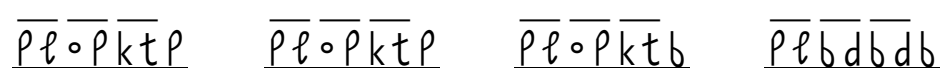

d. Sekaran III (laku telu)

III a: $\quad \overline{\rho p l} \overline{\rho b} \bar{\circ} \overline{\rho l} d \overline{\rho l} d o \overline{\rho l} \overline{\rho b} \circ \overline{\rho l p} \overline{\rho t} \overline{l p t}$

III b: 0 t th 0 tlt $\overline{t P} \overline{\rho l} \circ 0 d b$ ob $\overline{d b} \overline{k P} \quad 0$

e. Sekaran IV (Ukel pakis)

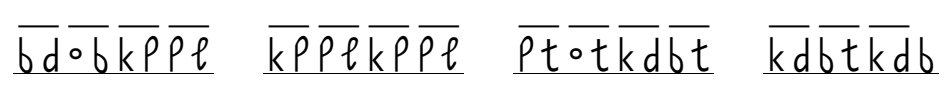

f. Sekaran V (kebyok sampur)
$\mathrm{Va}$ kt be $\overline{b l} \overline{\mathrm{kt}}$
$\overline{\mathrm{k} P} \overline{\mathrm{tb}} \overline{\rho l}$
$\overline{t k} \circ \bar{\rho} \overline{\rho l d}$
$\overline{t b} \bar{\circ} \overline{\rho l} \overline{k t}$
$\mathrm{V} b: \overline{k d} \overline{b t} \overline{k d} b$
$\overline{t k} \bar{\circ} \overline{\rho l d} \quad \overline{t k} \bar{\circ} \overline{\rho l d} \quad \overline{t b} \overline{\circ p} \overline{\rho l} \bar{t}$

g. Sekaran VIapa (tatapan)

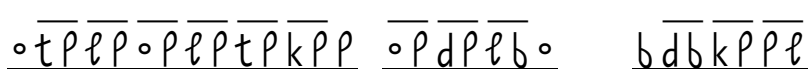

h. Sekaran VII (sekaran mlaku)

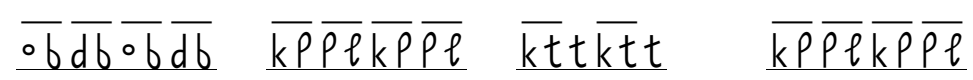

i. Sekaran VIII (sekaranmandek)

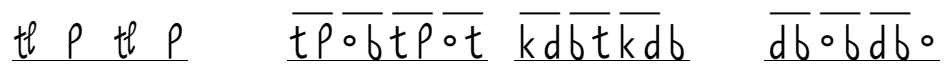

j. Sekaran IX (sekaran mlaku)

$$
\overline{p l b} b d b \overline{o b} b \overline{d b} \overline{\circ b} \text { b b d } \overline{p l} \text { obtpepp}
$$


Jurnal Etnomusikologi

k. SekaranX (mandek)

\section{$\overline{b 0} \overline{0} \overline{b 00} \overline{b l} \overline{k p} \circ \bar{\rho} \bar{\circ} \overline{\rho f b} \overline{d b} \overline{\circ b} \overline{\rho e b} \overline{d b} 0$}

1. Sekaran XI (mlaku)

$$
\overline{d b} \overline{\circ \rho} \overline{l \rho t} \overline{d b} \bar{\rho} \overline{l \rho} t \quad d t \overline{\rho l} d \overline{\rho l} d d t
$$

m. Sekaran menthokan (Mtk)

Mtk 1:

$\overline{d b} d d t d t o d$

Mtk 2: $0 \overline{t P} \overline{l P t} \overline{P l} d \circ \overline{t b} \overline{p l d} d t \quad d t \overline{p l d}$

a. SekaranMalik (ML)

\section{Pola Kendangan Singget}

Malik Pertama

ML 1:

$t \quad \overline{p P} \overline{p l} \bar{\rho} \overline{\rho l} \overline{\rho l} 0 \mathrm{~d}$

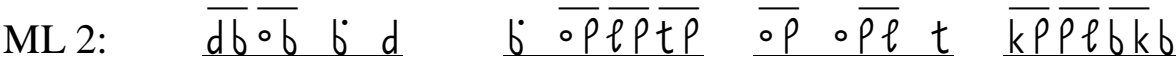

ML 3: $\overline{d b} \bar{\circ} f d$ f $\overline{\circ p} \overline{l t} \bar{p} \overline{\circ p} \circ p \overline{t P} \overline{\circ b} \overline{\circ P} \overline{d P} d$

Malik kedua dan seterusnya

ML 1:

$t \quad \overline{P P} \overline{P l} O \overline{P l} \quad d \overline{P l} O d$

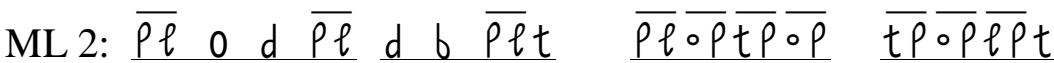

b. Magag $(\mathrm{Mg})$

Magag untuk gongan atau cengkok pertama rangkaian dari sekaran batangan

$\operatorname{Mg} 1$ :

$\overline{k \rho} \overline{\rho l} \overline{b d b} \overline{b d} \bar{\rho} \rho \overline{l \rho} \overline{\rho l} \overline{b d} \bar{b} \bar{b} \bar{d} b$

Mg 2: $\quad 0 \overline{k t \overline{k P 0}} \quad \overline{k t} \overline{P l} \overline{0 k} \circ \quad d t \overline{\circ P} \overline{P l} \overline{\circ k} \overline{\rho l} \overline{\circ k}$

Mg 3: $\overline{\circ k} t d \overline{t b} \quad \overline{\circ k} \overline{\rho l} \overline{\circ k}$ o $t \overline{\circ k} \overline{\rho l} \overline{\circ k} \overline{\rho l} \overline{\circ k}$

Magag untuk gongan atau cengkok kedua dan seterusnya.

Mg 1: $\quad \overline{k P} \overline{\rho l} \overline{b d} b \quad \overline{b d} \overline{\circ \rho} \overline{l \rho} \overline{\rho l} \overline{b d} \overline{b d} \overline{b d}$

Mg 2: $\overline{o f} d b \overline{t p} \overline{o p t l} \overline{p t p} \overline{o f} d b \overline{t p} \overline{o p t l} p t$ 


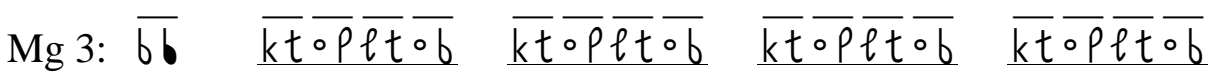

Mg 4: $\quad \overline{b d} t$ tl $P$ th $P$ te $P$ bd $t d b \quad d b d b$

Sekaran Magag Pungkasan (SMP), digunakan apabila akan suwuk

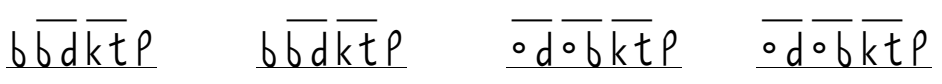

c. Kengser (Ks)

1. Kengser khusus untuk SekaranBatangan (KB)

$$
d \overline{t b} b \text { tp } \overline{p e} \overline{b d b} \overline{b d} \overline{b t} \overline{0 t \overline{t p}} \overline{t \rho} \overline{t b} d t
$$

2. Kengser (Ks) untuk umum.

Ks 1: ...... $\overline{k P} \overline{t \rho} \overline{l d} \overline{\rho l} \overline{b d} \overline{b d} \bar{b} b$

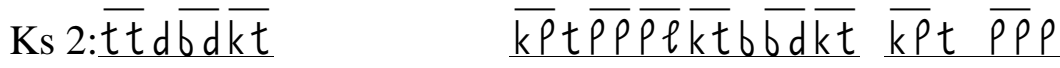

d. Ngaplak $(\mathrm{Ng})$

Ngpl 1: $\quad \overline{k P \rho l} \overline{b d b} \overline{b d} \overline{\circ \rho} \overline{l p} \overline{\rho l} \overline{k t} \overline{k P} t \overline{b d}$

Ngpl 2: $\circ \overline{\rho \ell} \overline{b d b} \overline{b d b \overline{t t} d} \overline{b d} \overline{\circ \rho} \overline{e p} \overline{\rho l} \overline{b d} \overline{b d} \overline{b d b}$

e. Ngaplak Susun (Ngpl Ss) digunakan setelah sekaran menthokan, menjelang andhegan. Ngaplak ini disajikan selalu mengikuti sekaran menthokan.

Ngpl Sn 1: $\quad \overline{k \rho} \overline{\rho l} \overline{b d b} \overline{b d} \overline{\circ \rho} \overline{l \rho} \overline{\rho l} \overline{k t} \overline{k P} \overline{t b}$

Ngpl Sn 2: $0 \overline{\rho \ell} \overline{b d b} \overline{b d} \overline{b t} \overline{t t} t \overline{k t t} t \overline{k t} t \overline{t h} b b$

Ngaplak susun kemudian diikuti sekaran kendangan mandheg seperti di bawah ini;

f. Sekaran Kendangan Mandheg

$$
\therefore t \overline{\rho P} \overline{\rho l} \circ \overline{\rho l} \quad \overline{b d} t d t \quad \overline{k P b} \rho t
$$

5. Urutan sekaran menjelang suwuk adalah sebagai berikut:

a. NgaplakSeseg digunakan bila akan suwuk

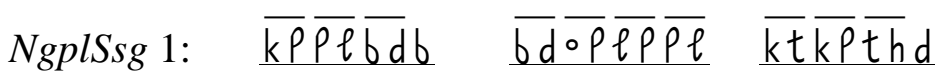

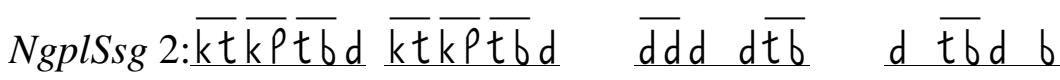


Jurnal Etnomusikologi

b. Gong seseg

$$
\overline{t b} d b \overline{t b} d b \overline{t b} \overline{\rho l} \overline{\rho l} \overline{\rho l} \overline{\rho l} \overline{\rho l} \text { b tok } \overline{\rho \rho \rho l}
$$

c. Sekaran Suwuk juga sering disebut sekaran kawilan

$S S w 1 ; 0 k \quad \overline{t b} \overline{o k} \overline{\rho l} \overline{\circ k}$ o $\overline{t b} \overline{\circ k} \overline{\rho l} \overline{o k} \overline{\rho l} \overline{\circ k} b$

$S S w 2: 0 k$ d $\overline{t h}$ ok $\overline{\rho l} \overline{\rho l} \overline{k t} b d P$ ok $\overline{t b} \bar{\circ} \overline{\rho l}$

d. Kengser Seseg (Kss)

Kss 1:

$\bar{k} \rho \bar{t} \overline{l d} \overline{\rho l} \overline{\rho l} \circ b \circ$

Kss 2: $\overline{b d} d d \overline{t b} d \overline{t b} d b \quad \overline{t b} \overline{p e} \overline{p e} \overline{p l} b$ tok $\overline{p l}$

e. MagagSeseg (Mg.ss.)

Mg.ss 1: $\quad \overline{\text { kP } \bar{\rho} \bar{b} \overline{d b}} \overline{d d} d d t \quad d \overline{t b} d b$

Mg.ss 2: $\overline{t h} d b \overline{t h} d b \overline{t h} \overline{\rho l} \overline{\rho l} \overline{\rho l} \overline{\rho l} \overline{\rho l}$ b t $\overline{0 k} \overline{\rho l}$

f. Kawilan $(K w)$

$$
0 k b \overline{t h} \overline{o k} \overline{\rho l} \overline{\circ k} \cdot \overline{\rho l} \bar{\rho} \overline{t h} \overline{k P} \rho P \text {. } P
$$

g. Suwuk $(S w k)$

$$
\text { Swk 1: } \cdot b \cdot p \quad p \cdot b
$$

Swk 2:,$P . \cdot . P .6$

Swk 3: kkkokkko kkkokoko

Aplikasi sekaran kendangan ciblon pada Gending Manuhara adalah seperti sebagai berikut: 
Tabel 2. Aplikasi sekaran kendangan ciblon pada Gending Manuhara

\begin{tabular}{|r|c|c|c|c|c|c|c|c|}
\hline No. & $\mathrm{A}$ & $\mathrm{B}$ & $\mathrm{C}$ & $\mathrm{D}$ & $\mathrm{E}$ & $\mathrm{F}$ & $\mathrm{G}$ & $\mathrm{H}$ \\
\hline 1 & .21 & .6 .5 & .2 .1 & .2 .3 & .5 .3 & .5 .3 & .6 .5 & .2 .1 \\
\hline 2 & .2 .1 & .6 .5 & .2 .1 & .2 .3 & .5 .3 & .5 .3 & .6 .5 & .2 .1 \\
\hline 3 & .2 .1 & .6 .5 & .2 .1 & .6 .5 & .6 .5 & .2 .1 & .3 .2 & .1 .6 \\
\hline 4 & .1 .6 & .1 .5 & .1 .6 & .1 .2 & .3 .1 & .3 .2 & .3 .1 & .6 .5 \\
\hline
\end{tabular}

Gending Manuhara, pada bagian inggahkenongan pertama dan kenong kedua menggunakan sekaran menthogan. Pola sekaran menthogan bisa disajikan, bilamana dalam satu kenongan terdapat setidaknya dua atau tiga gatraselehnya sama secara berurutan.

Keterangan penggunaan sekaran kendangan hubungannya dengan balungan gending pada gongan atau cengkok pertama sebagai berikut:

- 1A, 1B, 1C merupakan peralihan dari merong ke ciblon.

- 1D merupakan angkatanciblon.

- $\quad$ 1E berisikan sekaran batanganIa dan Ib

- $\quad 1 \mathrm{~F}$ berisikan sekaran batangan 1/4 Ia diteruskan kengser.

- $1 \mathrm{G}$ berisikan sekaran khusus Gending Manuhara.

- $1 \mathrm{H}$ berisikan seperempat sekaran khusus dilanjutkan kengser.

- 2A berisi dua sekaran pilesan (II).
- 2B berisikan satu setengah sekaran pilesan dilanjutkan kengser $(K s)$.

- 2C berisikan 1 1/4 sekaran pilesan (II), dilanjutkan ngaplak ( $\mathrm{Ngpl}$ )

- 2D berisikan kelanjutan ngaplak diteruskan sekaran menthokan.

- 2E berisikan dua sekaran menthokan.

- 2F berisikan setengah sekaran menthokan dilanjutkan kengser.

- 2G berisikan sekaran khusus Gending Manuhara.

- $2 \mathrm{H}$ berisikan seperempat sekaran khusus dilanjutkan kengser.

- 3A berisisekaran

- 3B berisi sekaran dan kengser

- 3C berisi sekaran dan ngaplak

- 3D berisi lanjutan ngaplak dan sekaran

- 3E berisi sekaran

- $\quad 3 F$ berisi sekaran dan kengser

- $\quad 3 \mathrm{G}$ berisi sekaran dan ngaplak 
- 3H berisi lanjutan ngaplak dan sekaran

- 4A berisi sekaran

- $\quad$ 4B berisi sekaran dan kengser

- 4C berisi sekaran

- 4D berisi sekaran dan malik

- $\quad 4 \mathrm{E}$ berisi malik

- $\quad$ 4F berisi malik dan sekaranmagag

- 4G berisi lanjutan sekaran magak dan ngaplak

- $\quad 4 \mathrm{H}$ berisi ngaplak dan sekaran

Gongan atau cengkok kedua, kenongan pertama dan kedua sebagai berikut:

- 1 A berisi dua sekarantatapan (VI)

- 1B berisikan satu setengah sekaran tatapan dilanjutkan kengser (Ks).

- $1 \mathrm{C}$ berisikan 1 1/4 sekaran tatapan (VI), dilanjutkan ngaplak (Ngpl)

- 1D berisikan kelanjutan ngaplak diteruskan sekaran menthokan.

- 1E berisikan dua sekaran menthokan.

- $1 \mathrm{~F}$ berisikan setengah sekaran menthokan dilanjutkan kengser

- 1G berisikansekaran khusus Gending Lambangsari.

- 1H berisikan seperempat sekaran khusus dilanjutkan kengser atau(VII) sekaran mlaku.

- 2A berisi dua sekaran (VII) sekaranmlaku.

- 2B berisikan satu setengah sekaran (VII) dilanjutkan kengser (Ks).
- 2C berisikan 1 1/4 sekaran (VII), dilanjutkan ngaplak ( $\mathrm{Ngpl})$

- 2D berisikan kelanjutan ngaplak susun diteruskan sekaran menthokan.

- 2E berisikan dua sekaran menthokan.

- 2F berisikan setengah sekaran menthokan dilanjutkan kengser

- 2G berisikansekaran khusus Gending Manuhara.

- $2 \mathrm{H}$ berisikan seperempat sekaran khusus dilanjutkan kengser atau sekaran(VIII) sekaranmandheg.

- 3A berisi sekaran

- 3B berisi sekaran dan kengser

- $3 C$ berisi sekaran dan ngaplak

- 3D berisi ngaplak seseg

- 3E berisi sekaran kawilan

- 3F berisi sekaran kawilan dan ngaplak seseg

- 3G berisi sekaran racut

- $3 \mathrm{H}$ berisi pergantian kendang ageng

- 4A, 4B berisi $\circ \circ \circ t P p \circ P \quad P b \circ P$

- 4C, 4D berisi $p \circ \circ \underline{6 P \circ b}$

- 4E, 4F berisi $\quad p \circ b P$ $\circ \circ \circ b \circ \overline{t b} \bar{k}$ 
- 4G,4H berisi $\circ \circ \circ \rho \circ \circ \circ b$

\section{$k k k \circ k k k \circ k k k \circ k \circ k$}

\section{Simpulan}

Gending Manuhara Laras Pelog Patet Lima merupakan salah satu gending yang tergolong gending baru, karena gending ini selesai dicipta tanggal 19 September 2013. Adapun pencipta gending Manuhara adalah K.R.R.A. Saptodiningrat. Gending Manuhara berbentuk gending ageng yaitu gending kethuk 2 awis minggah 8, terdiri dari buka, merong, umpak inggah dan inggah. Keistimewaan gending Manuhara adalah pada bagian merong terdiri atas limakenongan, dan satu-satunya gending laras pelog patet lima yang digarap menggunakan kendang ciblon dan menggunakan sekaran menthokan. Sampai saat sekarang ini tidak ada gending ageng pelog lima yang bisa digarap ciblon. Gending Manuhara dicipta khusus sebagai gending klenengan dan gending ini tercipta dari lagu suluk pelog lma ageng.

\section{E. Daftar Pustaka}

Djumadi, 1975, Titilaras Rebaban Jilid I, Akademi Seni Karawitan Indonesia, Surakarta.

Hadari Nawawi, 1987, Metodologi Penelitian Bidang Sosial, Gajah Mada University Press, Yogyakarta.

John W. Creswell, 2014, RESEARCH DESIGN Pendekatan Kualitatif, kuantitatif, dan Mixed, Penerbit Pustaka Pelajar Yogyakarta, Yogyakarta.

Lexy J. Moleong, 2014, Metodologi Penelitian Kualitatif, Penerbit PT. Remaja Rosdakarya Bandung, Bandung.

Koentjaraningrat, 1991, Metode-Metode Penelitian Masyarakat, Gramedia, Jakarta.

Martopangrawit, R.1, 1975, Pengetahuan Karawitan Jilid I, Akademi Seni Karawitan Indonesia Surakarta.

Moh.Nasir, 1988, Metode Penelitian, Ghalia, Jakarta, Indonesia.

Mloyowidodo, 1973, Balungan Gending Jilid I, II, III, Bagian Reserch Konservatori Karawitan Indonesia Surakarta.

Mujanattistama, 1977, Pedhalangan Ngayogyakarta, Jilid I, Yayasan Habirandha, Yogyakarta.

Nyoman Kutha Ratna, 2010, Metodologi Penelitian Kajian Budaya Dan Ilmu Sosial Humaniora Pada Umumnya, Pustaka Pelajar Yogyakarta, Yogyakarta. 
Prajapangrawit, R.Ng, 1990, Serat Sujarah

Utawi Riwayating Gamelan

Wedhapradangga, STSI

Surakarta dengan Fort

Foundation, Surakarta.

RahayuSupanggah,2002,

Bothekan

KarawitanI, Ford Foundation

dan Masyarakat Seni

Pertunjukan Indonesia,

Surakarta.

2009, Bothekan Karawitan II

GARAP , Program Pascasarjana

bekerja sama dengan ISI Press,

Surakarta.

2011, Dunia Pewayangan di Hati Seorang Pengrawit, ISI Press Solo, Surakarta.

Rustopo, 2014, Perkembangan GendingGending Gaya Surakarta 19502000-an, ISI Press Solo, Surakarta.

Soeroso, 1983, Gamelan B, Departemen Pendidikan dan Kebudayaan Direktorat Jendral Pendidikan Dasar dan Menengah, Direktorat Jendral Pendidikan Menengah Kejuruan, Proyek Pengadaan Buku Pendidikan Menengah Kejuruan, Jakarta.

Slamet Suparno, 2006, Pendekatan Sosiologis, dalam Penelitian Karawitan ISI Surakarta, Surakarta.

S. Probohardjono, 1966, Sulukan Sléndro, Ratna, Surakarta.

Sri Hastanto, 2009, Konsep Pathet, Dalam Karawitan Jawa, Program Pascasarjana bekerjasama dengan ISI Press, Surakarta.
Sumardi Suryabranta, 1988, Metode Penelitian, CV. Rajawali, Jakarta.

Sumarsam, 2002, Hayatan Gamelan Pendalaman Lagu, Teori, dan Persepektif, STSI Press, Surakarta.

Sutrisno Hadi, 1991, "Pokok - Pokok Metodologi Penelitian Ilmiah" Sebuah Naskah dalam rangka Penataran Metode Penelitian Tenaga Pengajar ISI Yogyakarta tanggal 5 dan 6 Agustus 1991.

Waridi, 2008, Gagasan \& Kekaryaan Tiga Eтри Karawitan, Penerbit Etnoteater Publisher, BaccKota Bandung bekerja sama dengan Pascasarjana ISI Surakarta, Surakarta. 